\title{
The Microstructure and Properties of Copper with Ceria Nanoparticles Addition
}

\author{
Daniela Passarelo Moura da Fonseca, Waldemar Alfredo Monteiro \\ Nuclear and Energy Research Institute, IPEN, Cidade Universitária, São Paulo, Brazil \\ Email: danipassarelo@hotmail.com,wamontei@ipen.br
}

How to cite this paper: da Fonseca, D.P.M. and Monteiro, W.A. (2019) The Microstructure and Properties of Copper with Ceria Nanoparticles Addition. Journal of Materials Science and Chemical Engineering, 7, 40-48.

https://doi.org/10.4236/msce.2019.710004

Received: September 20, 2019

Accepted: October 19, 2019

Published: October 22, 2019

Copyright $\odot 2019$ by author(s) and Scientific Research Publishing Inc. This work is licensed under the Creative Commons Attribution International License (CC BY 4.0).

http://creativecommons.org/licenses/by/4.0/

\section{Open Access}

\begin{abstract}
Copper-based composites strengthened by ceria nanoparticles were processed by conventional powder metallurgy: mixing ( $30 \mathrm{~min}$ and $46 \mathrm{rpm}$ ), compaction (cold, uniaxial, $1080 \mathrm{MPa}$ for $10 \mathrm{~s}$ ) and sintering $\left(800^{\circ} \mathrm{C}\right.$ for $6 \mathrm{~h}$ in vacuum atmosphere of $10^{-5}$ torr). It was studied the microstructure (optical microscopy, scanning electron microscopy), X-ray diffraction with Rietveld refinement and some properties (electrical conductivity, Vickers hardness and fracture analysis) of the compositions $92 \mathrm{wt} \% \mathrm{Cu}-8 \mathrm{wt} \% \mathrm{CeO}_{2}$ and $80 \mathrm{wt} \%$ $\mathrm{Cu}-20 \mathrm{wt} \% \mathrm{CeO}_{2}$. The results showed uniform phase distribution, low porosity and ceria disperse inside copper grain. In despite of properties, the composites had electrical conductivity of 38\% IACS and 15\% IACS and hardness of 69 and $88 \mathrm{HV}_{5}$, respectively. The results of $92 \mathrm{wt} \% \mathrm{Cu}-8 \mathrm{wt} \% \mathrm{CeO}_{2}$ composites were promising, and they are in according with actual literature.
\end{abstract}

\section{Keywords}

Copper-Based Composites, Ceria, Microstructure, Electrical Conductivity, Hardness

\section{Introduction}

Copper is widely used in electrical and electronic applications due to its high electrical conductivity; even so, its low mechanical resistance is a barrier for some applications who requires high mechanical stress.

Metal matrix composites (MMCs) consist in adding ceramic particles in a soft metal with the aim to improve its mechanical resistance; however, this reinforcing phase also increases the scattering of electrons on the material and, consequently, decreases its electrical conductivity. The main challenge of MMCs researches is to get values of electrical conductivity who allow commercial uses of the material [1] [2] [3]. Various inert particles such as $\mathrm{SiC}, \mathrm{SiO}_{2}, \mathrm{Al}_{2} \mathrm{O}_{3}, \mathrm{ZrO}_{2}$ and 
$\mathrm{TiO}_{2}$ have been used as reinforcement phase. Ceria is a rare earth oxide that has outstanding properties like high coefficient of thermal expansion, low thermal conductivity, good corrosion resistance, high melting point and chemical and thermal stability [4] [5]. Its high coefficient of thermal expansion is a special asset for MMCs processed by powder metallurgy, because of the mismatch between the coefficient of thermal expansion of the metallic matrix and ceramic reinforcement usually causes thermal stresses during sintering stage.

Composite $88 \mathrm{wt} \% \mathrm{Cu}-12.2 \mathrm{wt} \% \mathrm{CeO}_{2}$ prepared by electrodeposition exhibited increased microhardness and wear resistance than the pure copper coating, reaching the maximum value of $280 \mathrm{HV}_{0.05}$, this hardness improvement comes from crystallite size refinement in the copper matrix structure, produced by ceria dispersion [4]. In according to this, another study observed that ceria may increase the hardness of the copper as long its particles has been finely dispersed in the matrix, the presence of agglomerates in the composite microstructure could decrease the hardness. The authors observed that it is more difficult to avoid the occurrence of this agglomerates as ceria contents increases [5] [6] [7] [8]. Composite $\mathrm{W}-\mathrm{Cu}$ with $1 \mathrm{wt} \%$ and $2 \mathrm{wt} \%$ of ceria processed by powder metallurgy exhibit, respectively, electrical conductivity of $47 \%$ IACS and $40 \%$ IACS, they also show some porosity, aggregated particle and lower density than sample without ceria addition [7].

There are just a few studies concerning the microstructure and the properties of composites strengthened by $\mathrm{CeO}_{2}$. In this scenario, the aim of this work was to process copper-based MMCs by powder metallurgy and study the microstructure and some properties (electrical conductivity, hardness and fracture) of the composites $92 \mathrm{wt} \% \mathrm{Cu}-8 \mathrm{wt} \% \mathrm{CeO}_{2}$ and $80 \mathrm{wt} \% \mathrm{Cu}-20 \mathrm{wt} \% \mathrm{CeO}_{2}$.

\section{Experimental}

Copper (given by Metallic Materials Laboratory of the Nuclear and Energy Research Institute) and Ceria (Sigma-Aldrich, average size $<25 \mathrm{~nm}$ ) powders were mixed in a cylindrical mill for $30 \mathrm{~min}$ and $46 \mathrm{rpm}$, followed by cold compaction into cylindrical pellets (diameter: $10 \mathrm{~mm}$ ) using uniaxial hydraulic press with applied pressure of $1080 \mathrm{MPa}$ for $10 \mathrm{~s}$. The green samples were then sintered and solubilized in a tubular furnace $\left(800^{\circ} \mathrm{C}, 6 \mathrm{~h}\right.$, and vacuum atmosphere $10^{-5}$ torr) at a heating rate of $10^{\circ} \mathrm{C} / \mathrm{min}$. After these steps, it was obtained cylindrical samples with diameter $10 \mathrm{~mm}$, high $1.5 \mathrm{~mm}$ and mass $1 \mathrm{~g}$. It was also processed a standard sample of $100 \mathrm{wt} \% \mathrm{Cu}$ under the same conditions of composite samples.

The as received copper and ceria powders were characterized by particle size analyzer (only copper powder, CILAS 1064), Scanning Electron Microscope (SEM) with Electron Dispersive X-ray Spectroscope (EDS) (JSM-6010LA JEOL), Transmission Electron Microscope (TEM) (only ceria powder, JEM 2100F JEOL) and Xray Diffractometer (XRD) (Rigaku Multiflex, $\mathrm{Cu} \mathrm{K} \alpha$ ).

Microstructure of the composites was investigated by Optical Microscope (OM) (BX51M Olympus), SEM, EDS and XRD. Rietveld refinement was carried 
out using the GSAS/EXPGUI software and ICSD (Inorganic Crystal Structure Database) files 64699 (copper) and 61595 (ceria), the crystallite size was calculated from the Lorentzian broadening coefficient (LX):

$$
p=\frac{18,000 K \lambda}{\pi \mathrm{LX}}
$$

where $p$ is the crystallite size in $\mathrm{nm}, K=1$ is the Scherrer constant and $\lambda$ the radiation wavelength (in this case $0.154 \mathrm{~nm}$ ). Beside the crystallite size, it was acquired from the Rietveld refinement values of phase quantification and cell parameter.

Strengthening of the composites was estimated by hardness measurement using a Vickers hardness tester (Buehler 5100) applying a load of $5 \mathrm{kgf}$ for a dwell time of $15 \mathrm{~s}$, it was made 9 indentation for sample and it was used adequate number of samples of each composition. Electrical conductivity was measured with an eddy-current instrument (Foerster Sigmatest 2068) using a probe of 14 $\mathrm{mm}$ diameter and $60 \mathrm{kHz}$ frequency, it was made 5 measurement for sample and it was used adequate number of samples of each composition. Density was calculated using experimental values of high, diameter and mass of samples; theoretical density was calculated from the rule of mixtures taking fully dense values for copper and ceria 8.95 and $7.65 \mathrm{~g} \cdot \mathrm{cm}^{-3}$, respectively.

\section{Results}

\subsection{Powder Characterization}

The SEM and TEM images of the powders are shown in Figure 1. The powders
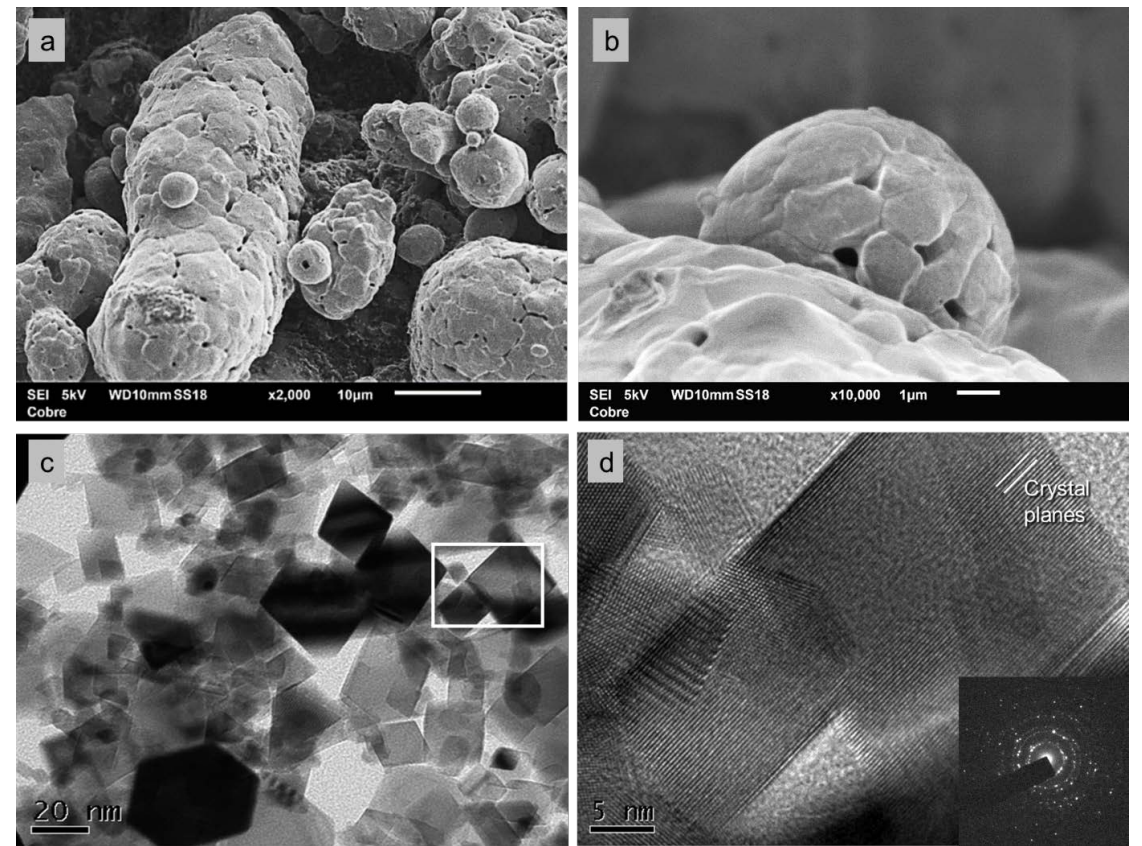

Figure 1. (a) and (b) SEM images of copper powder, irregular spheres with mean particle diameter of $39.86 \mu \mathrm{m}$; (c) and (d) TEM images of ceria powder, monocrystalline particles smaller than $25 \mathrm{~nm}$. 
analysis indicated that copper particles has shape of irregular spheres and mean particle diameter of $39.86 \mu \mathrm{m}$. Ceria has faceted monocrystalline particles with different geometries and it is possible to infer by TEM images that they are smaller than $25 \mathrm{~nm}$, in according with powder producer report. The EDS microanalysis identify just the expected elements of each powder (100 wt\% $\mathrm{Cu}$ and $86.39 \mathrm{wt} \%$ $\mathrm{Ce}-13.61 \mathrm{wt} \% \mathrm{O})$. The XRD analysis showed thin peaks and the expected phases $\left(\mathrm{Cu}\right.$ and $\left.\mathrm{CeO}_{2}\right)$, with crystallite size of $93.1 \mathrm{~nm}$ and $28.9 \mathrm{~nm}$, respectively.

\subsection{Microstructure of Composites}

SEM (Figure 2) and OM (Figure 3) images shows for both compositions a microstructure with good densification and with fine grains, the ceria phase was finely dispersed in the grain. In the composite with higher concentration of ceria (Figure 3(b)), it is possible to observe copper particles completely isolated by the ceria. Due to some particles agglomerated in the powder, it was observed larger phases of ceria from these agglomerates.

The composites presented homogeneity in the distribution of the phases and of the microstructure along the height and diameter with microstructure like the normal direction. The absence of segregation could indicate that the mixing process was efficient, mixing using cylindrical mill ensured uniform distribution of the particles in works of Venkateswaran et al. [9] and ASM International [10]. Among the samples, there was a maximum variation in height of $0.2 \mathrm{~mm}$.

The composite with $20 \mathrm{wt} \% \mathrm{CeO}_{2}$ had internal cracks (indicated by the arrows in Figure 3(d)) in the horizontal direction (perpendicular to the compaction direction), this type of crack can occur during the beginning of compaction and during the removal of the compacted from the matrix.

As the pressure is released from the upper punch to the sample, the sample expands elastically and uniaxially because it tends to return to its original situation, due to sample stiffness or the friction of the matrix wall, this expansion does not occur at the edges, generating the cracks. In the withdrawal, the upper part is released from the compression forces of the matrix wall and undergoes lateral expansion while the lower part is still inside the matrix, in this transient stage shear stresses occur generating the cracks [11] [12] [13].
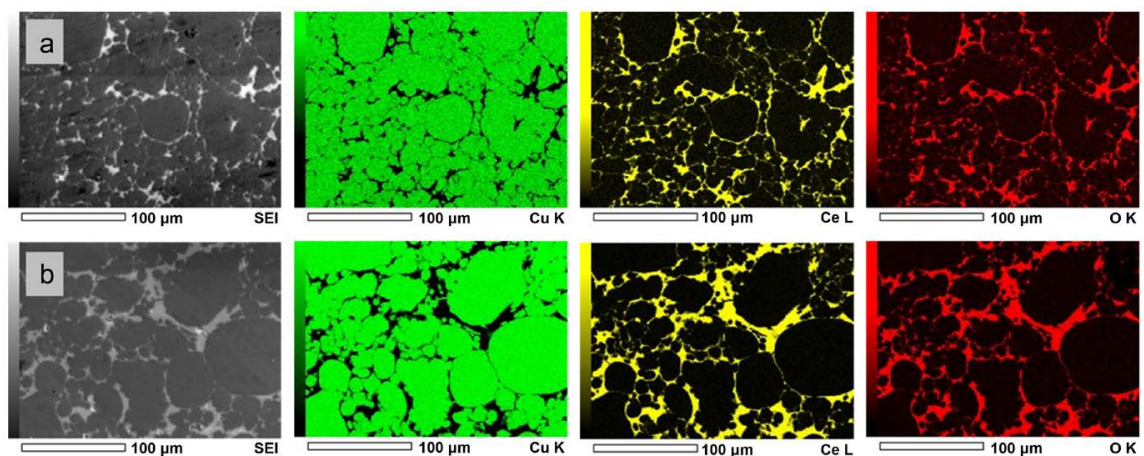

Figure 2. SEM images of (a) $92 \mathrm{wt} \% \mathrm{Cu}-8 \mathrm{wt} \% \mathrm{CeO}_{2}$ and (b) $80 \mathrm{wt} \% \mathrm{Cu}-20 \mathrm{wt} \% \mathrm{CeO}_{2}$. Ceria phase is finely dispersed in the grain boundary. 


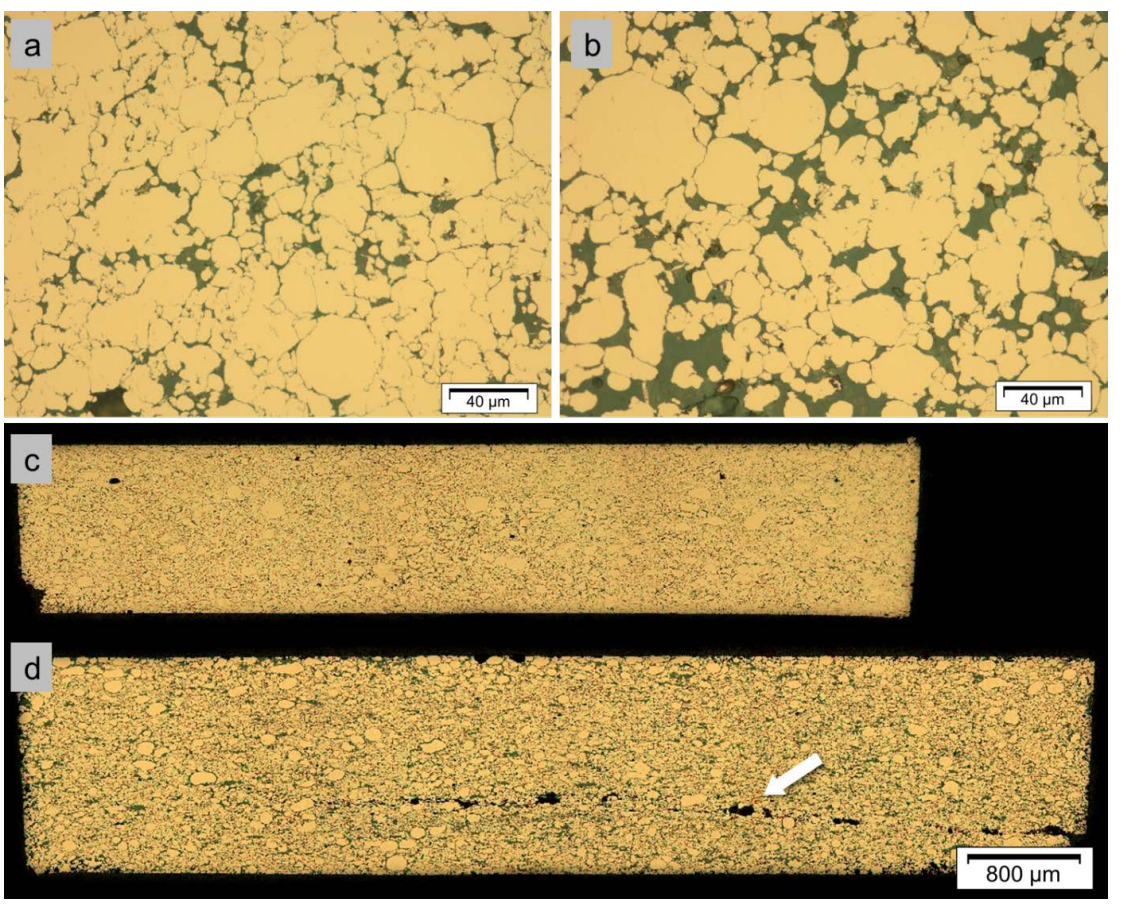

Figure 3. $\mathrm{OM}$ images of $92 \mathrm{wt} \% \mathrm{Cu}-8 \mathrm{wt} \% \mathrm{CeO}_{2}$ in (a) normal and (c) transversal directions; 80 wt $\% \mathrm{Cu}-20$ wt $\% \mathrm{CeO}_{2}$ in (b) normal and (d) transversal. Microstructure with good densification of copper particles and homogeneity in the distribution of the phases and of the microstructure along the height and diameter. The arrow indicates internal cracks.

Figure 4 shows the XRD pattern of the composites obtained experimentally ("obs") accompanied by Rietveld calculated curve ("calc") and the difference among these curves ("diff"), it is also showed the identification of each peak (phase and planes). It was identified just the expected phases $\left(\mathrm{Cu}\right.$ and $\left.\mathrm{CeO}_{2}\right)$. The oxidation of copper $\left(\mathrm{Cu}_{2} \mathrm{O}\right)$ at high temperature is a very common phenomenon to occur and has been reported by several authors, however, in the XRD patterns there is no indication of peak at the diffraction angles of this phase, which indicates that the control of the vacuum during sintering was efficient. There is a shift in the (200) peak of the copper to positions $2 \theta$ smaller for all the composites, that can be observed by the format of the curve "diff" in the position of the $2 \theta-50^{\circ}$ (Figure 4). The same occurs in the pure copper sample (processed under the same conditions), this type of displacement of the (200) peak occurs in $\mathrm{CFC}$ materials due to the increase in the probability of intrinsic stacking failure [14].

The crystalline structure of both, copper and ceria, is Face Centred Cubic where, in the case of ceria, the tetrahedral interstitial is filled by oxygen. Table 1 shows phase quantification, crystallite size and cell parameter for each phase of the composites. The crystallite size of the copper phase in the composites with 8 and $20 \mathrm{wt} \% \mathrm{CeO}_{2}$ was 61.0 and $72.6 \mathrm{~nm}$, respectively, whereas in the pure copper sample it was $82.8 \mathrm{~nm}$. This may indicate that ceria has restricted grain growth of copper. 


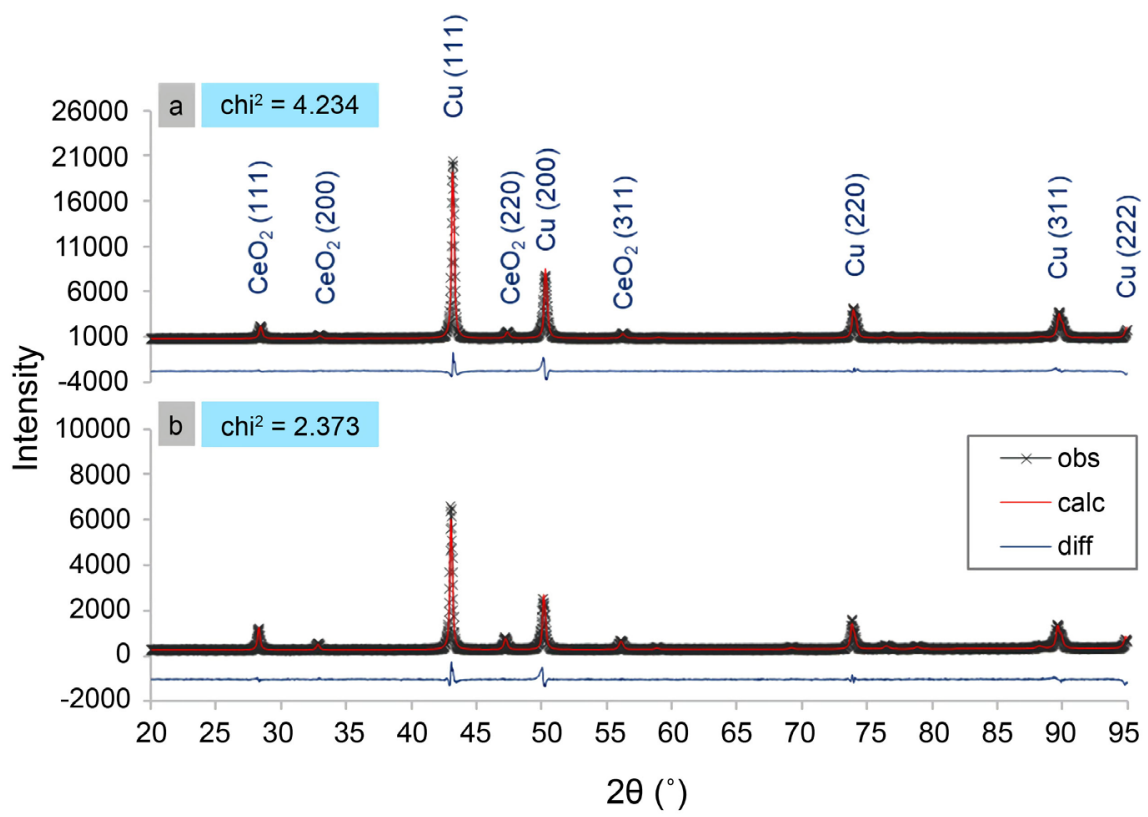

Figure 4. XRD patterns of (a) $92 \mathrm{wt} \% \mathrm{Cu}-8 \mathrm{wt} \% \mathrm{CeO}_{2}$ and (b) $80 \mathrm{wt} \% \mathrm{Cu}-20 \mathrm{wt} \%$ $\mathrm{CeO}_{2}$. It was identified just the expected phases $\left(\mathrm{Cu}\right.$ and $\left.\mathrm{CeO}_{2}\right)$ and a shift in (200) copper peak, due increase in the probability of intrinsic stacking failure.

Table 1. Properties of $\mathrm{Cu}-\mathrm{CeO}_{2}$ composites.

\begin{tabular}{|c|c|c|c|}
\hline & & $92 w t \% \mathrm{Cu}-8 \mathrm{wt} \% \mathrm{CeO}_{2}$ & 80 wt $\% \mathrm{Cu}-20$ wt $\% \mathrm{CeO}_{2}$ \\
\hline \multicolumn{2}{|l|}{ Density $\left(\mathrm{g} \cdot \mathrm{cm}^{-3}\right)$} & $8.12 \pm 0.05$ & $7.66 \pm 0.03$ \\
\hline \multicolumn{2}{|c|}{ Specific gravity (\%) } & 92 & 88 \\
\hline \multicolumn{2}{|c|}{ Electrical conductivity (\%IACS) } & $38 \pm 5$ & $15 \pm 3$ \\
\hline \multicolumn{2}{|c|}{ Vickers Hardness $\left(\mathrm{HV}_{5}\right)$} & $69 \pm 2$ & $88 \pm 4$ \\
\hline \multirow{2}{*}{ Phase quantification (wt\%) } & $\mathrm{Cu}$ & $91.90 \pm 0.05$ & $82.75 \pm 0.06$ \\
\hline & $\mathrm{CeO}_{2}$ & $8.1 \pm 0.2$ & $17.2 \pm 0.2$ \\
\hline \multirow{2}{*}{ Crystallite size (nm) } & $\mathrm{Cu}$ & 61.0 & 72.6 \\
\hline & $\mathrm{CeO}_{2}$ & 40.1 & 49.0 \\
\hline \multirow{2}{*}{ Cell parameter (nm) } & $\mathrm{Cu}$ & $0.361825 \pm 0.00009$ & $0.36182 \pm 0.0001$ \\
\hline & $\mathrm{CeO}_{2}$ & $0.54135 \pm 0.0004$ & $0.54149 \pm 0.0003$ \\
\hline \multirow{3}{*}{ EDS (wt\%) } & $\mathrm{Cu}$ & 9.13 & 85.30 \\
\hline & $\mathrm{Ce}$ & 6.58 & 13.30 \\
\hline & $\mathrm{O}$ & 0.28 & 1.55 \\
\hline
\end{tabular}

\subsection{Properties of Composites}

Table 1 shows some properties of the composites. The pure copper sample had a conductivity of $74 \%$ IACS, a sample of pure cast had a conductivity of $99 \%$ IACS copper (with the same equipment and parameters of copper and composites samples), which suggests that there is a loss of electrical conductivity about of $25 \%$ that is intrinsic to the processing. However, the conductivity obtained for 
the composite with $8 \mathrm{wt} \% \mathrm{CeO}_{2}$ is adequate and it is in according to the values found in previous works with copper-based composites [5] [15] [16].

The addition of the ceramic phase increased the hardness of copper, because ceria is inherently harder. Varying the percentage of the ceramic reinforcement from 8 to $20 \mathrm{wt} \%$ the hardness increased from 69 to $88 \mathrm{HV}_{5}$. This behavior exposes good physical adhesion between the metal-ceramic phases [17] [18].

Part of the reason for the hardness not being so high may be due to sintering/homogenization time [19]. For example, Rajkovic et al. [15] observed that the hardness decreases from 1050 to $410 \mathrm{MPa}$ after subjecting $\mathrm{Cu}-4 \% \mathrm{Al}_{2} \mathrm{O}_{3}$ composite to high temperatures $\left(800^{\circ} \mathrm{C}\right.$ for $\left.5 \mathrm{~h}\right)$.

Figure 5 shows the observation of fractographs of the composites using SEM. It is observed a mixed fracture, fragile fracture regions (indicated by the arrows) suggest good adhesion in the matrix-reinforcement interface [20]. In the fractography of the composite $80 \mathrm{wt} \% \mathrm{Cu}-20 \mathrm{wt} \% \mathrm{CeO}_{2}$ the presence of dimples is not clearly observed (at least with this magnification) and the fracture is predominantly fragile.

\section{Conclusions}

The copper-based composites reinforced with ceria were processed by powder metallurgy and had their microstructures and properties studied, the conclusions are as follows:

- Copper and ceria powders had morphology, composition and particle sizes suitable for sample processing.

- The composites $92 \mathrm{wt} \% \mathrm{Cu}-8 \mathrm{wt} \% \mathrm{CeO}_{2}$ and $80 \mathrm{wt} \% \mathrm{Cu}-20 \mathrm{wt} \% \mathrm{CeO}_{2}$ were processed by conventional powder metallurgy (mixing, compaction and sintering) and presented oxidation-free surface and relative density of $88 \%$ and $92 \%$, respectively.

- The microstructure shows good matrix densification, low porosity and good adhesion between phases with finely dispersed ceria in the copper grain boundary. The EDS microanalyses did not indicate any element other than expected. The XRD patterns did not indicate the formation of other phases beyond that expected and indicated.
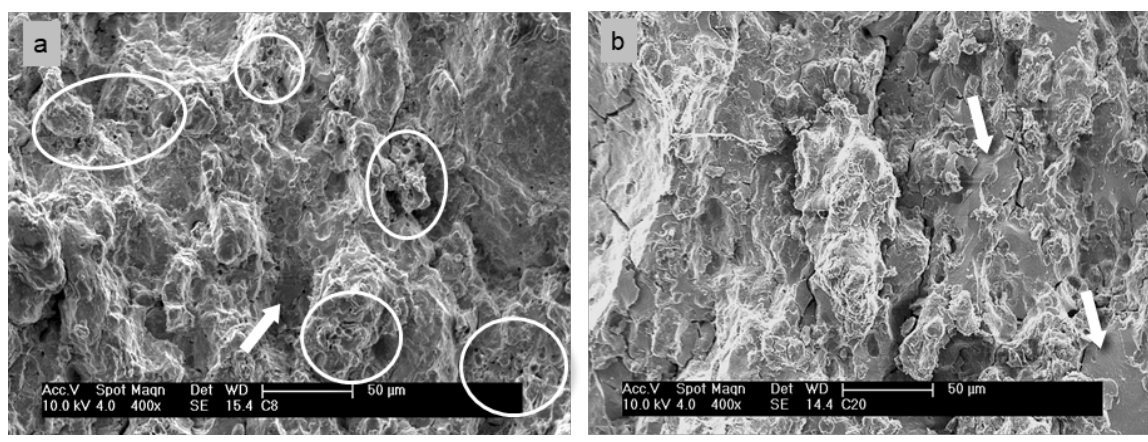

Figure 5. Fractographies of (a) $92 \mathrm{wt} \% \mathrm{Cu}-8 \mathrm{wt} \% \mathrm{CeO}_{2}$ and (b) $80 \mathrm{wt} \% \mathrm{Cu}-20 \mathrm{wt} \%$ $\mathrm{CeO}_{2}$. The circles indicate ductile fracture and the arrows indicates fragile fracture. 
- The values of electrical conductivity obtained were $38 \%$ IACS and $15 \%$ IACS but reached $51 \%$ and $21 \%$ in relation to the pure copper sample processed under the same conditions.

- The Vickers hardness values were 69 and $88 \mathrm{HV}_{5}$, representing $230 \%$ and $293 \%$ of the hardness of the pure copper sample.

- The composites presented mixed fracture (ductile and brittle); the fractographs also indicated that the composite $92 \mathrm{wt} \% \mathrm{Cu}-8 \mathrm{wt} \% \mathrm{CeO}_{2}$ is more ductile.

- Studies have suggested that with $20 \mathrm{wt} \% \mathrm{CeO}_{2}$ the electrical conductivity and fracture behavior of the composite are compromised, however, with $8 \mathrm{wt} \%$ $\mathrm{CeO}_{2}$ promising results were obtained.

\section{Acknowledgements}

This work was supported by Brazilian graduate fellowship (CAPES).

\section{Conflicts of Interest}

The authors declare no conflicts of interest regarding the publication of this paper.

\section{References}

[1] Lu, L., Shen, Y., Chen, X., Qian, L. and Lu, K. (2003) Ultrahigh Strength and High Electrical Conductivity in Copper.

[2] ASM International (2001) Specialty Handbook: Copper and Copper Alloys.

[3] Raabe, D., Miyake, K. and Takahara, H. (2000) Processing, Microstructure, and Properties of Ternary High-Strength $\mathrm{Cu}-\mathrm{Cr}-\mathrm{Ag}$ in Situ Composites. Materials Science and Engineering A, 291, 186-197. https://doi.org/10.1016/S0921-5093(00)00981-3

[4] Ramalingam, S., Muralidharan, V.S. and Subramania, A. (2013) Electrodeposition and Characterisation of $\mathrm{Cu}-\mathrm{CeO}_{2}$ Nanocomposite Coatings. Surface Engineering, 29, 511-515. https://doi.org/10.1179/1743294413Y.0000000153

[5] Mangam, V., Bhattacharya, S., Das, K. and Das, S. (2010) Friction and Wear Behavior of $\mathrm{Cu}-\mathrm{CeO}_{2}$ Nanocomposite Coatings Synthesized by Pulsed Electrodeposition. Surface \& Coatings Technology, 205, 801-805. https://doi.org/10.1016/j.surfcoat.2010.07.119

[6] Mangam, V., Das, K. and Das, S. (2010) Structure and Properties of Electrodeposited $\mathrm{Cu}-\mathrm{CeO}_{2}$ Nanocomposite Thin Films. Materials Chemistry and Physics, 120, 631-635. https://doi.org/10.1016/j.matchemphys.2009.12.017

[7] Lu, Z., Luo, L., Chen, J., Huang, X., Cheng, J. and Wu, Y. (2015) Fabrication of $\mathrm{W}-\mathrm{Cu} / \mathrm{CeO}_{2}$ Composites with Excellent Electric Conductivity and High Strength Prepared from Copper-Coated Tungsten and Ceria Powders. Materials Science \& Engineering A, 626, 61-66. https://doi.org/10.1016/j.msea.2014.12.047

[8] Sharma, A., Bhattacharya, S., Das, S. and Das, K. (2013) Fabrication of Sn-Ag/CeO Electro-Composite Solder by Pulse Electrodeposition. Metallurgical and Materials Transactions A, 44, 5587-5601. https://doi.org/10.1007/s11661-013-1894-5

[9] Venkateswaran, K., Kamaraj, M. and Prasad, R.K. (2007) Dry Sliding Wear of a Powder Metallurgy Copper-Based Metal Matrix Composite Reinforced with Iron Aluminide Intermetallic Particles. Journal of Composite Materials, 41, 1713-1728. 
https://doi.org/10.1177/0021998306069888

[10] ASM International (1998) ASM Metals Handbook-Volume 7 Powder Metal Technologies and Applications.

[11] HÖGANÄS (2013) Höganäs Handbook for Sintered Components-Production of Sintered Components.

[12] Richerson, D.W. (2005) Modern Ceramic Engineering: Properties, Processing and Use in Design. 3rd Edition, Taylor and Francis, Philadelphia. https://doi.org/10.1201/b18952

[13] Balakrishna, P., Chakraborthy, K.P. and Singh, A. (1996) End-Capping and Other Defects in Pressed Ceramic Compacts. Indian Journal of Engineering \& Materials Sciences, 3, 196-200.

[14] Mittemeijer, E.J. and Scardi, P. (2004) Diffraction Analysis of the Microstructure of Materials. Springer, Berlin. https://doi.org/10.1007/978-3-662-06723-9

[15] Rajkovic, V., Bozic, D. and Jovanovic, M.T. (2010) Effects of Copper and $\mathrm{Al}_{2} \mathrm{O}_{3}$ Particles on Characteristics of $\mathrm{Cu}-\mathrm{Al}_{2} \mathrm{O}_{3}$ Composites. Materials and Design, 31, 1962 1970. https://doi.org/10.1016/j.matdes.2009.10.037

[16] Bera, S., Chowdhury, S.G., Lojkowsky, W. and Manna, I. (2012) Synthesis of CuCr and $\mathrm{CuCrAg}$ Alloys with Extended Solid Solubility with Nano- $\mathrm{Al}_{2} \mathrm{O}_{3}$ Dispersion by Mechanical Alloying and Consolidation by High Pressure Sintering. Materials Science \& Engineering A, 558, 298-308. https://doi.org/10.1016/j.msea.2012.08.004

[17] Daoushb, W.M., Lima, B.K., Moa, C.B., Nama, D.H. and Honga, S.H. (2009) Electrical and Mechanical Properties of Carbon Nanotube Reinforced Copper Nanocomposites Fabricated by Electroless Deposition Process. Materials Science and Engineering $A$, 513-514, 247-253. https://doi.org/10.1016/j.msea.2009.01.073

[18] Panda, S., Dash, K. and Ray, B.C. (2014) Processing and Properties of Cu Based Micro- and Nano-Composites. Bulletin of Materials Science, 37, 227-238. https://doi.org/10.1007/s12034-014-0643-8

[19] Rajkovic, V., Bozic, D. and Jovanovic, M.T. (2008) Properties of Copper Matrix Reinforced with Nano- and Micro-Sized $\mathrm{Al}_{2} \mathrm{O}_{3}$ Particles. Journal of Alloys and Compounds, 459, 177-184. https://doi.org/10.1016/j.jallcom.2007.04.307

[20] Chawla, N. and Chawla, K.K. (2006) Metal Matrix Composites. Springer, New York. https://doi.org/10.1002/9783527603978.mst0150 